\title{
ENRIQUE DE VILLENA COMO POETA Y DRAMATURGO: BOSQUEJO DE UNA POLÉMICA FRUSTRADA
}

Enrique de Villena (más estrictamente, don Enrique de Aragón) es uno de los más conocidos prosistas de la primera mitad del siglo $\mathrm{xv}$ y disfruta, además, fama popular de nigromante. Otro aspecto de su reputación se ha estudiado menos: algunos escritores contemporáneos y posteriores parecen aludir a poesías de Villena, aunque no constan en las bibliografías obras poéticas suyas. En efecto, una consideración generosa de las referencias a la obra poética de Villena entre sus contemporáneos, $y$, si se aceptan, los versos atribuidos a Villena por varios críticos a lo largo de los siglos, podrían sugerir un amplio cancionero o diwän villenesco, compuesto de poemas perdidos y de fragmentos sobre asuntos genialmente diversos.

I Referencias en el siglo XV a la aCtividad Pó́tica de Villena

Son cinco las alusiones que pueden interpretarse como referencias a la creación poética de Villena entre sus contemporáneos. Estas citas han sido recogidas y analizadas por Amador de los Ríos y Cotarelo y Mori ${ }^{1}$. Como veremos, los dos críticos difieren en sus conclusiones. Los comentarios de los cinco autores medievales presentan un problema especial: Si existiese un solo verso indudable mente escrito por Villena, sería fácil concluir que todos se refieren a su obra poética. La retórica de los elogios -metáforas y símiles normalmente reservados para describir un don poético creador, referencias a la autoridad de Villena entre los poetas- evoca un retrato que, para cualquier otro sujeto, sería el de poeta. Pero la falta de muestras concretas de sus poesías nos obliga a considerar

I José AMAdor DE los Ríos, Historia critica de la literatura española, t. 6, Madrid, 1865, pp. 76, 170; Emillo Cotarelo y Mori, Don Enrique de Villena: su vida y obras, Madrid, 1896, pp. 122-124. 
los posibles significados secundarios de sus palabras. Los trozos ambiguos son los siguientes:

a) Fernán Pérez de Guzmán, Generaciones y semblanzas, cap. sobre "Don Enrique de Villena, que fue fijo de don Pedro e Marqués de Villena" (ed, por R. B. Tate, Londres, 1965, p. 33) : "Todavía fue muy sotil en la poesía e grant estoriador e muy copioso e mezclado en diversas ciencias". La frase "fue muy sotil en la poesía" ofrece alguna ambigüedad: la primera interpretación sería que fue gran poeta. Pero, a la vez, se puede entender que sabía mucho sobre la poesía o la teoría poética (lo cual confirman los fragmentos conservados de su Arte de trovar), o que fue muy hábil traductor de la poesía extranjera (la Eneida, la Divina comedia).

b) Iñigo López de Mendoza, Marqués de Santillana, Defunsión de don Enrique de Villena, señor doto $e$ de exçelente ingenio (en Cancionero castellano del siglo $x v$, ed. R. Foulché-Delbosc, I Madrid, 1912; $N B A E$, t. 19, núm. 168, p. 508), estrofa 3:
Mas yo a ti sola me plaze llamar, o cithara dulçe más que la de Orpheo, que sola tu ayuda non dubdo, mas creo mi rústica mano podrá ministrar. $O$ bibliotheca de moral cantar, o fuente meliflua, do mana eloquençia, infunde tu graçia e sacra prudençia en mí, porque pueda tu planto expresar.

El epíteto "cíthara dulçe" serviría normalmente para elogiar un talento poético, y una frase como "fuente meliflua" para referirse a su creación parece indicar que Santillana conocía alguna producción poética de Villena. Joaquín Gimeno Casalduero, en su análisis de la Defunsión, cree que el retrato es de Villena como poeta, capaz de competir incluso con Orfeo, pero la alusión no se refiere "al poder creador de don Enrique, sino al poder inductor de su poesía" " (No tiene en cuenta Gimeno Casalduero la polémica sobre la existencia de poemas de Villena). Pero también pueden interpretarse estas frases descriptivas como referencias al papel más directo de Villena -que tradujo para el Marqués la $D i$ vina comedia- en la inspiración de Santillana.

Otras estrofas del Marqués de Santillana -generalmente incluidas en su Comedieta de Ponza, aunque deben haber formado parte de su Defunsión de don Enrique de Villena ${ }^{3}$ - parecen clasificar

2 "La Defunsión de Don Enrique de Villena del Marqués de Santillana: Composición, propósito y significado", HRL, 2, 269-283; la cita, p. 271.

B Véase Cotarelo y Mori, op. cit., pp. 120-121, quien se inclina por el 
como poeta a Don Enrique de Villena de una forma más explícita (Canc. cast. del s. xv, I, estrofas 27 y 28 de la Comedieta, p. 464):

Las sílabas cuenta e guarda el açento producto e correto; pues en geometría Euclides non ovo tan grand sentimiento, nin fizo Athalante en astrología. Oyó los secretos de philosophia e los fuertes passos de naturaleza; obtuvo el intento de la su pureza e profundamente vio la poesía.

Las sonantes cuerdas de aquel Anphión que fueron de Thebas muralla e arreo, jamás non ovieron tanta perfecçión como los sus cursos melifluos, yo creo. Pues de los más sabios, alguno non leo nin jamás he visto que asy los entienda de su grand loquela resçiben emienda los que se coronan del árbol laureo.

Si eliminamos el problema monumental de estas estrofas -es decir, si aluden a Villena y pertenecen a la última parte de la $D e$ funsión, tal como aparecen en el Canc. general de Hernando del Castillo, o si se refieren al rey D. Alfonso de Aragón, según las presenta la Comedieta - es evidente que describen los métodos superiores de un poeta practicante. Constiutyen a la vez un elogio de su técnica ("las sílabas cuenta e guarda el açento / producto y correto...") y de su seriedad profesional ("obtuvo el intento de la su pureza / e profundamente vio la poesía"). Pero, de nuevo, la alusión aparentemente definitiva a una creación poética de Villena da pie a múltiples interpretaciones.

texto del Cancionero general de Castillo, cuyas estrofas pertenecen a la sección final de la Defunsión: "si se suprimen [de la Defunsión] queda incompleta y defectuosa...; porque después de haber empleado veinte coplas para llegar a $D$. Enrique, apenas dicen las Musas nada de él..." Cree Cotarelo que los copistas de la Comedieta se aprovecharon de las coplas para elogiar a Alfonso de Aragón, aunque "no cuadran tan exactamente como a D. Enrique". Sin embargo, Gimeno Casalduero parece no aceptar tal reconstrucción, que no se ajusta a sus consideraciones estructurales de la Defunsión; y Manuel Durán, en su edición reciente de las Poesias completas del Marqués de Santillana, Madrid, 1975, pp. 236, 253, ni siquiera alude a la versión apoyada por Cotarelo. Maxim P. A. M. Kerkhof, en sus ediciones de la Comedieta y de la Defunsión, acepta sin comentario que estas estrofas pertenecen a la Comedieta: D. Iñigo López de Mendoza, Marqués de Sanillana, La comedieta de Ponza, Groningen, 1976, pp. 186-187; Defunsión de don Enrique de Uillena, señor docto $e$ de exçellente ingenio, de f́nigo López de Mendoza, Marqués de Santillana, Groningen, [1977;], p. 103. 
c) Juan de Mena, El laberinto de Fortuna o Las trescientas (ed. J. M. Blecua, Madrid, 1943, reimpr. 1968; Clás. Cast., 119, pp. 69-71), estrofas 126-128. Parece muy posible que la materia incluida por Mena en su largo elogio de Villena se refiera a su obra poética $(127 a-d)$ :

aquel claro padre, aquel dulçe fuente, aquel que en el cástalo monte resuena, es don Enrrique, señor de Villena, onrra de España e del siglo presente.

Otra vez, las frases "aquel dulçe fuente" (como la "cíthara dulçe" evocada por Santillana) y "aquel que en el cástalo monte resuena" parecen recursos de una retórica reservada al encomio de temperamentos artístico-poéticos. Como indica María Rosa Lida de Malkiel, la nota principal en la serie de tres estrofas dedicadas a Villena en el Laberinto es elogio a él -y sólo a él-como gran cultivador de las ciencias en su época ${ }^{4}$. Pero Mena parece añadir a este retrato tradicional de Villena la faceta de artista o, por lo menos, de autoridad y presencia en el mundo de los poetas.

d) Juan Alfonso de Baena, "Respuesta... [al dezir que] fizo e ordenó Diego d'Estúñiga contra Juan Alfonso de Baena como a manera de rrequesta, e soo entençión de le baldonar e afear por quanto avía tomado rrequesta contra todos los mariscales e todos los otros", en Cancionero de Baena. (ed. por José María Azáceta, III, Madrid, 1966, núm. 425, p. 894) :

En Buytrago o en Villena

aprendiste el deytar,

e non vos podrá ayudar

Fray Diego de Muxena;

esto es, synple escolar,

porque quesystes tentar

al que vos puede sangrar

vuestras syenes con barrena

a ssabor del paladar.

4 Juan de Mena: poeta del prerrenacimiento español, México, 1950, p. 226. Para Derek C. CARR, "Los doze trabajos de Hércules: Fuente posible del Laberinto de Juan de Mena", $H R, 41$ (1973), 417-420, el elogio en el Laberinto no sólo indica la amistad entre Villena y Mena, sino también se refiere al hecho de que la obra de Villena ha tenido un papel importante en el Laberinto, y específicamente en la estrofa 65. Aquí invoca Mena dos trabajos apócrifos de Hércules que no se encuentran entre las doce labores tradicionales. Según Carr, proceden de los Doze trabajos, que incluyen (trabajos 3 y II) los dos episodios introducidos por Mena. R. G. Keightley, "Boethius, Villena and Juan de Mena", BHS, 55 (1978) 189-202, se niega a aceptar las conclusiones de Carr, y prefiere la hipótesis de una fuente común. 
Indica Cotarelo y Mori (Villena, p. 123) que hay dos maneras de interpretar estos versos curiosos. Según la lectura más obvia, Baena insinúa aquí que Diego de Estúñiga imita los versos de "Buytrago" (es decir, el Marqués de Santillana, quien se identifica en algunas obras como "fñygo López, senyor de Buytrago"; véase el Canc. cast. del s. xv, I, p. 568b), y también los versos de Villena. Pero a la vez se presenta la posibilidad de que se refiera a los versos o las técnicas del Marqués de Santillana, y a la teoría poética de Villena en su Arte de trovar.

e) Fernán Móxica, poeta en la corte de Juan II (versos citados por Amador de los Ríos, Historia critica, VI, p. 170; Cotarelo y Mori, Villena, p. 123):

Mas Enrique de Villena

con el barón de la Vega,

alumbren mi mano ciega

faciendo conclusión llena.

Aquí, como en los versos de Baena, el poeta invoca a Villena, igualmente con Santillana, como modelo o impulso en la creación poética ${ }^{5}$.

Estas referencias algo vagas de la poesía medieval -que pueden haber sido en parte elogios exagerados por sus contemporáneos- han llevado a incluir a Enrique de Villena en la nómina de los poetas. Sobre esta base postulan varios críticos un amplio repertorio de poemas villenescos. Juan Antonio Pellicer y Saforcada (Ensayo de una biblioteca de traductores españoles, Madrid, 1778, p. 62), hablando del papel de Villena en las justas poéticas de Barcelona, dice que "Del lugar tan privilegiado que en ellas ocupaba el Marqués se infiere no tanto la alta calidad de su persona, como la superioridad de su ingenio poético, en el cual dice Don Nicolás Antonio que no era inferior a ninguno de sus contemporáneos" ". Amador de los Ríos concluye automáticamente que los elogios medievales se refieren a su producción poética:

5 Otros poemas del siglo $\mathrm{xv}$ en que aparece Villena con varios papeles aunque sin alusiones directas a su producción poética, son los siguientes: Marqués de Santillana, Pregunta de nobles, que fizo el Maraués de Santillana a don Enrique, Señor de Villena, en Canc. cast. del s. xv, I, pp. 496497; Diego de Burgos, Tractado intitulado Triunfo del Marqués, a loor y reverencia del yllustre y maravilloso señor don Yñigo López de Mendoça, ibid., II, donde se incluye un retrato de Villena parecido al que encontramos en Generaciones y semblanzas (Triunfo, p. 546), y donde se dedica una estrofa (p. 551) a las opiniones de Villena sobre los atributos del Marqués (véase Joaquín Arce, "El Triunfo del Marqués de Diego de Burgos y la irradiación dantesca en torno a Santillana", $R U M, 19,1971,25-39$ ).

- Las opiniones de Nicolás Antonio se encuentran infra, p. 65. 
“...y recibido en Castilla tan peregrino documento [el Arte de trovar de Villena], al paso que extendía entre los eruditos la fama de trovador que le habían ganado sus poemas, conquistábale también nombre y autoridad de maestro" (Historia critica, VI, p. 76). El título de un artículo de Edmund Dorer, "Heinrich von Villena, ein spanischer Dichter und Zauberer", Archiv für das Studium der neueren Sprachen und Litteraturen, 78 (1887), 129-144, también le clasifica implícitamente ?

Sin duda, como veremos, los ambiguos elogios medievales provocaron las especulaciones de los investigadores de los siglos xvI$\mathrm{xIx}$, sobre la actividad poética de Villena. El conjunto de las interpretaciones de aquellos textos sugestivos pero indefinidos, las confusiones sobre el género de obras específicas de Villena, los manifiestos errores en la identificación del autor de ciertas obras, e incluso la creación de poemas apócrifos o falsificados atribuidos a Villena por investigadores atrevidos, parecen sugerir que existió un cuerpo amplio de obras poéticas ahora perdidas. $\mathbf{Y}$ esta fama de poeta puede ser aumentada aún más por el error comprensible de algunos críticos modernos, que confunden a Enrique de Villena (es decir, Enrique de Aragón, llamado erróneamente "Marqués de Villena") con dos poetas de nombre o título semejante, de cuya obra poética hay claros testimonios: el Infante D. Enrique de Aragón (1399-1445), hijo tercero de D. Fernando de Antequera y legítimo Marqués de Villena, y, por supuesto, pariente de Enrique de Villena (véase Eloy Benito Ruano, "Fortuna literaria del Infante D. Enrique de Aragón", Archivum, 14, 1964, 161-201) ; y Diego López Pacheco, favorito de Enrique IV y poeta conocido, quien también llevaba el título de Marqués de Villena ${ }^{8}$.

En realidad, no nos queda ningún verso original que se pueda

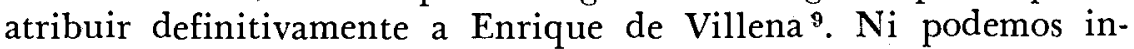

7 Por otra parte, la reacción de Cotarelo y Mori ante los mismos trozos incluye una nota de escepticismo: "A la verdad, el genio del autor del Arte cisoria era lo menos poético del mundo, y quizá estos testimonios de contemporáneos suyos deban tener una interpretación distinta de la que comúnmente suele dárseles" (op. cit., p. 123). En las obras literarias que se dedican a Villena a partir del siglo xvi, se alude más que nada a su labor de nigromante; véase Samuel Waxman, "Chapters on Magic in Spanish Literature (Chap. III: Enrique de Villena, the magician)", $R H i, 38$ (1916), 325-464, especialmente pp. 387-438. Sin embargo, hay un eco lejano de la leyenda de Villena, poeta, en el Doncel de Don Enrique el Doliente (1834) de Mariano José de Larra, donde Guzmán le describe: "afeminado cortesano, un intrigante ambicioso, un rimador, un nigromante..." (citado en Waxman, p. 427).

8 Véase Kerth Whinnom, Diego de San Pedro, New York, 1974, pp. 22 24 y 136. Examinamos ciertos aspectos de esta confusión en pp. 78-80.

- Seguramente pertenecen a otro autor los versos añadidos como suple- 
vocar el conocido mito de la gran quema de la biblioteca de Villena (como hizo Felipe Benicio Navarro ${ }^{10}$ ) para explicar la pérdida de su hipotética obra poética ${ }^{11}$. Parece muy dudoso $-\mathrm{a}$ pesar de la alusión de Juan de Mena (Laberinto, estr. 126-128) que fuesen entregadas a las llamas las obras originales de Villena. Es posible, como opina Menéndez Pelayo (Biblioteca de traductores, I, p. 137), que perecieran algunos escritos sobre la magia y las artes adivinatorias, o sobre la astrología y la alquimia. Pero no cabe la posibilidad de que la obra estrictamente literaria -incluyera poesías o no- también fuese quemada.

Para explicar todo esto -el testimonio de los elogios de Villena, poeta, junto a la ausencia absoluta de versos suyos-, Menéndez Pelayo propone la tesis de un Villena joven, poeta, seguido por un Villena erudito y no muy aficionado a escribir poesías originales en su madurez:

D. Enrique de Villena hizo versos, sin duda, pero no creemos que fuese muy fecundo ni muy aplaudido poeta. De otro modo, ¿cómo se explicaría el raro fenómeno de habernos quedado de él tantas y $\tan$ diversas obras en prosa, y no conservarse un solo verso suyo en los innumerables cancioneros del siglo $\mathrm{xv}$, que no ya a tanta medianía, sino a tanto poetastro y coplero insulso dieron franca hospitalidad?... Lo más verosímil es que D. Enrique de Villena no hizo versos más que en su juventud, y éstos quizá en catalán más bien que en castellano, y luego abandonó definitivamente la poesía para dedicarse a otras erudiciones. Sólo así se explica su total ausencia del pobladísimo parnaso de los Cancioneros (Antología de poetas líricos castellanos, t. 2, Madrid, 1944, p. 49).

mento al Arte cisoria o Tractado del arle de cortar del cuchillo (1423) de Villena, en el manuscrito escurialense F-IV-1, fol. $86 \mathrm{v}$ (cortado e imperfecto), recogidos en la edición de Felipe Benicio Navarro, Madrid-Barcelona, 1879, p. 121: "Otro cortar del cochillo / sé yo que non sabe otro / que después del gallo cocho / non se pare con la qresta / e dan la con la ballesta / como corderro de punto; / el gallo que non tiene vnto / non fase finar la olla. / Señores como quien rronda / e díselo que parresçe / os rruego que non se asconda / la honrra a quella meresçe. / El cortar del sesto cochillo / ay vn terçio de avantaje..." -Véase también Julí́n Zarco CuEvas, Catálogo de los manuscritos castcllanos de la Real Biblioteca de El Escorial, I, Madrid, 1924, p. 143. (La edición más reciente del Arte cisoria por Enrique Diaz-Retg, Barcelona, 1948, no recoge estos versos.)

10 Arte cisoria, p. xlvi.

11 Para noticias sobre la amplia controversia en torno a la célebre quema de libros de Villena, véase Menéndez Pelayo, Biblioteca de traductores españoles, t. 1, Madrid, 1952 (t. 54 de la Edición Nacional), pp. 135-137; ThÉodore de Puymaigre, "Don Enrique de Villena et sa bibliotheque", Retue des Questions Historiques, 11 (1872), 526-534; S. WAXMAN, art. cit., pp. 390 396; Leonie F. SAchs, "Enrique de Villena: Portrait of the magician as an outsider", SPhi, 64 (1967), 109-131; Nicholas G. Round, "Five magicians, or the uses of literacy", MLR, 64 (1969), 793-805. 
Esta teoría resulta aceptable en lo que se refiere a los datos generales de la biografía de Villena. Es decir, la época de su participación en las fiestas poéticas o los espectáculos alegóricos en verso -como veremos- terminó en 1414, cuando tendría unos 29 años. $Y$ tales actividades presuponen cierta categoría o aceptación en los círculos poéticos de la primera parte del siglo $\mathrm{xV}-\mathrm{O}$ como artista, o como experto en la teoría poética, o como crítico entusiasta. Pero, por otra parte, no tiene en cuenta Menéndez Pelayo el hecho de que la fama (auténtica o hipotética) de Villena como poeta nace, o se conoce, por unos ambiguos elogios o referencias, que le son dedicados muy tarde en su vida o poco después de su muerte. Si aceptamos como prueba los elogios, es lógico que se refieren no a una predilección abandonada por Villena en su juventud, sino a las actividades conocidas de su madurez.

\section{Referencias a la poesía de Villena a PARTir del siglo XVI}

Los testimonios de un conocimiento aparentemente directo de la poesía de Villena aumentan a partir del siglo xvi. Como apunta Cotarelo y Mori (p. 124), el primero que aludió a la existencia de unos versos de Villena fue Don Gonzalo Argote de Molina (1548/9-1596). En el "Discurso sobre la poesía castellana" que aparece como suplemento a su edición del Conde Lucanor (Sevilla, 1575; Madrid, 1642), lamenta que los poetas hayan abandonado el uso de la copla antigua (es decir, los versos octosílabos, que contrastan con los nuevos metros italianizantes). Tales poetas, dice Argote de Molina, deben seguir "el ejemplo de este príncipe [Don Juan Manuel] y el de otros caballeros muy principales castellanos, que se pagaron mucho de esta composición, como fueron el rey D. Alonso el Sabio, el rey D. Juan el Segundo, el marqués de Santillana, Don Enrique de Villena y otros de los quales leemos coplas y canciones de muy gracioso donaire” ${ }^{12}$. ¿Cuáles son las composiciones poéticas de Villena, en versos breves del antiguo estilo, que declara haber visto Argote de Molina? No se refiere a ninguna de las obras atribuidas a Villena por investigadores posteriores - las Façañas de Hércules, el Libro del tesoro, o los versos escritos para la coronación de Fernando de Antequera- puesto que éstas son o de arte mayor (Façañas, Tesoro) o de versos anómalos más largos (versos para la coronación). Eleuterio F. Tiscornia, en sus notas al párrafo citado de Argote de Molina (pp. 81-82), con-

12 Citamos por la edición de Eleuterio F. Tiscornia, Discurso sobre la poesia castellana, Madrid, 1926, p. 32. 
cluye que los únicos versos de la producción poética de Villena - para él seguramente mínima- son cinco líneas recogidas en el Cancionero de Hernando del Castillo, todas de ocho sílabas o menos. Pero, como explicaremos (cf. infra, pp. 78-88), es muy probable que estos versos no sean de Enrique de Villena, sino de Diego López Pacheco, Marqués de Villena. ¿Es que Argote de Molina añadió el nombre de Villena a una lista de autoridades, sin tener presente un ejemplo concreto de la poesía de Villena, o es que se equivocó, o tal vez vio unas "coplas y canciones" de Villena después desaparecidas para siempre? ${ }^{18}$

En el siglo xvn también fue clasificado Villena como poeta, y también por un investigador ilustre. Nicolás Antonio (1617-1684) menciona una obra de Villena, Los doze trabajos de Hércules, como obra en verso: "Liber Dé los trabajos de Hercules inscriptus, carmine, ut credimus, Burgis prodiit..." (Bibliotheca hispana vetus, II, Madrid, 1788, p. 222). Como apunta George Ticknor (History of Spanish Literature, t. 1, Boston, 1849, p. 331, nota 33), recogen también esta falsa información Luis José Velázquez (Origenes de la poesía castellana, Málaga, 1754, p. 49), y Leandro Fernández de Moratín (Origenes del teatro español, ed. Eugenio de Ochoa, París, 1838, p. 58). Además, el comentario general de Nicolás Antonio sobre las dotes poéticas de Villena resulta tan ambiguo como los elogios medievales: "acumine poetico nulli fuit temporis secundus..." (Bibl. vetus, $\S 158$, p. 221). Este juicio fue ampliamente difundido entre los historiadores de la literatura, como en la ya citada declaración de Pellicer y Saforcada (Ensayo de una bibliotheca, p. 62), sobre el "ingenio poético" de Villena, "que no era inferior a ninguno de sus contemporáneos". (Véase Cotarelo y Mori, p. 123).

En los siglos xviII y xIx hay toda una serie de obras poéticas atribuidas a Enrique de Villena. Cada atribución -tanto las patentemente absurdas como las relativamente bien fundadas- encierra en sí una polémica que va a prolongarse hasta nuestros días. Blas Nasarre, en el prólogo a su edición de Comedias y entremeses

13 Otro crítico temprano, que alude al talento poético de Villena, aunque sin indicar si se refiere a sus poemas o a su teoría poética, fue Hernán Núñez. En sus glosas a la edición que preparó del Laberinto de Juan de Mena, dice: "Diose al estudio de la sciencia y supo mucho no sólo en la poesía, philosophía, astrología, mas aun en el arte de la mágica" (citado por WAXman, art. cit., p. 393). Basándose sin duda en tales referencias, George Ticknor creía que había un cuerpo de textos de Villena. En 1842, escribió a Pascual de Gayangos, pidiéndole que le mandara una copia de "Selections from the Marquis de Villena's poetical works to the amount of 30 folio pages; -if so much can be found" (George Ticknor: Letters to Pascual de Gayan. gos, ed. por Clara Louisa Penney, New York, 1927, p. 43). 
de Cervantes (Madrid, 1749), identificó a Villena como autor y director de un drama alegórico del cual se conservan unos versos, vertidos del catalán al castellano por un cronista del siglo xv. Leandro Fernández de Moratín, en su Origenes del teatro español (publicado póstumamente en 1830), aseguró que fue Villena quien escribió el enigmático Libro del tesoro. Felipe Benicio Navarro, en la introducción a su edición del Arte cisoria de Villena (MadridBarcelona, 1879), le declaró autor de las Façañas de Hércules, texto del que se conservan sólo dos estrofas, y que es una obra distinta de los Doze trabajos de Hércules, en prosa. Incluso en la época moderna, los investigadores siguen atribuyendo a Villena unos versos que circulaban en los cancioneros del siglo xvI. Cada una de estas obras identificadas provisional o definitivamente por varios eruditos como creación de Villena, merece un estudio separado; pero en su conjunto, tales atribuciones no hacen más que acrecentar la pirámide de especulaciones sobre el papel o la leyenda de Villena poeta.

\section{Obras de Villena, o atribuidas a Villena, Relacionadas CON LA POESÍA}

a) Obras no escritas en verso que tienen que ver con la teoria poética, o con la traducción de poemas. Antes de estudiar los diversos poemas citados como piezas de Villena, cabe examinar sus proyectos poéticos, y las varias manifestaciones de su amplia preocupación por las metas de la poesía. Si estas actividades no le confirman como poeta, al menos lo sitúan en la inmediata periferia de la producción poética. En primer lugar, parece que organiza espectáculos alegóricos durante su estancia en Zaragoza y Barcelona el Consistorio de la Gaya Ciencia, y preside sus fiestas poéticas. Seguramente, su libro sobre los métodos de versificar -el Arte de trovar (1433), que se conserva sólo en parte- nace de estas actividades ${ }^{14}$. Como proyecto largo e intensivo, emprende la traducción de dos poemas - la Divina comedia de Dante (traducción

14 Véase la edición de F. J. Sánchez Cantón, "El Arte de trovar de don Enrique de Villena", RFE, 6 (1919), 158-180. La opinión general es que las justas poéticas que preside Villena, y que describe en su texto, son de la época de Fernando de Antequera, en 1414. (Además, cita Pellicer y SAforCADA, Ensayo de una bibliotheca, pp. 62-63, un poema llamado Aganipe del "Doctor Andrés" [de Uztarroz] en que se relata así el motivo de las fiestas mencionadas en el Arte de trovar: "Y quando D. Enrique de Villena / con D. Fernando vino / a la insigne Barcino, / el Apolíneo gremio / de su fecunda y elegante vena / ilustró con aplausos y con premio..." También estudian los versos Cotarelo, pp. 123, y Navarro, Arte cisoria, p. xlv). Pero 
terminada en 1427) y la Eneida de Virgilio (1428). Finalmente, aunque el estilo habitual de sus tratados es algo seco, pedante, y antipoético, hay momentos en que revela cierta capacidad poética. (El prólogo al Tractado sobre la lepra es el ejemplo más evidente ${ }^{15}$ ). Y en los Doze trabajos de Hércules (escrito originalmente en catalán en 1417, pero vertido al castellano por el autor en el mismo año), examina Villena varias teorías sobre el arte poético: el valor y los límites de la ficción literaria, el empleo de metáforas, imágenes, y símiles, el papel de la alegoría, y su propia teoría del estilo poético ${ }^{18}$.

Las traducciones de la Divina comedia y la Eneida parecen haber sido elaboradas con miras más bien académicas que poéticas. Básicamente, podemos decir que ambas son en prosa, aunque la nueva edición de la traducción de Dante, magistralmente empezada por José A. Pascual, nos sugiere que Villena pudo haber intentado al principio una traducción en verso. Aunque el manuscrito presenta la disposición gráfica de la prosa, es evidente que Villena traduce verso por verso, y que a veces experimenta con la rima. Ilustran este proceso las primeras líneas de su traducción del Infierno:

Martín de Riquer ("Don Enrique de Villena en la corte de Martín I", $H H A$, $2,717.727$ ) ya considera la posibilidad de que las actividades mencionadas en el Arte de trovar no correspondan al reinado de Fernando, sino al de Martín 1: "Si leemos este pasaje [del Arte de trovar] prescindiendo de las adiciones de Alvar Gómez no cabe duda de que la fiesta descrita por don Enrique de Villena la situaremos en el reinado de Martín el Humano" (p. 721).

15 Véase la edición de $\mathrm{L}$. Contreras Poza, publicada como suplemento a la edición de Alonso Chirino, Menor daño de la medicina y Espejo de medicina, preparada por el mismo Contreras Poza con A. González Palencia, Madrid, 1945, p. 615: "Durmiendo en alegre sueño, veyéndome en deleitoso vergel por alcançar de un fermoso fruto, tengo que fuese espiritual, teniendo con la una mano la rrama baxada a mí queriendo ya tomar con la otra. El qual sueño entiendo de cabo de mandar e fuy yo despertado adesora. Ca senti entrar una vieja tosiendo e muy de vieja hedat la qual en el tossido se me rrecordó que en mi niñez la avía cognoscido. $\mathrm{E}$ dormitando yo dixo quién anda ay. Respondió: yo, la que te avía tan olvidado como tú a mí. Enbíame tu señor don Enrique al qual tú amas servir, toma la letra e rresponde. Yo dixe: luego luego. $\mathrm{E}$ atiendo tomé la péñola e escreví por lo qual tengo que conçierna a la vuestra alta çiençia munchas emiendas fazer a los errores que asy se escriven". Véase también la edición de J. Soler $(=\mathrm{R}$. Foulché-Delbosc [?]), "Tres tratados" [Tratado de la consolación, 110-182; Aojamiento, 182-197; Lepra, 198-214], RHi, 41 (1917), p. 198.

16 Véase Margherita Morreale, en la introducción a su edición de Doze trabajos, Madrid, 1958, pp. xI-xxvi. Sobre la originalidad de Villena en sus opiniones sobre la poesía, al lado de la tesis expresada en su fuente principal, consúltese también M. Morreale, "Coluccio Salutati's De Laboribus Herculis (1406) and Enrique de Villena's Los doze trabajos de Hércules (1417)", SPhi, 51 (1954), 95-106, especialmente pp. 99-101. 
En el medio del camino de nuestra vida me fallé por una espesura o silva de árboles obscura en do el derecho camino estava amatado. E quanto a dezir quál era es cosa dura, esta selva salvaje áspera e fuerte que pensando en ella rrenueva el mi miedo. Tanto era amarga que poco más es la muerte, mas por contar o tractar del bien que yo en ella fallé, diré de las otras cosas que a mí ende fueron descubiertas ${ }^{17}$.

Este arreglo nos lleva a pensar que el proyecto inicial de Villena era la traducción en verso, pero que lo abandonó a poco de comenzar ${ }^{18}$; o, posiblemente, que lo que tenemos es una versión provisional o preliminar de la traducción, y que el autor pensaba rehacer más tarde su trabajo en forma poética. Lo que apoya la segunda hipótesis es la existencia -en los versos 2 y 8 del trozo que acabamos de citar - de palabras alternativas: "espesura o silva", "contar o tractar".

De todos modos, no se refleja en la traducción de la Divina comedia el gran ingenio poético que alababan los contemporáneos de Villena. Como comenta Mario Schiff ante unas muestras de la empresa villenesca, "elle est par endroits assez réussie et presque partout d'une fidélité qui tient plus du calque que de la traduction artistique" 19. Confirman esta opinión los estudios de Farinelli, Arce Fernández, Penna, y Pascual ${ }^{20}$. La tarea de traducir la Eneida parece haber sido iniciada y llevada a cabo con propósito semejante ${ }^{21}$.

17 Citamos la edición de Pascual, La traducción de la "Divina Comedia" atribuida a D. Enrique de Aragón: estudio y edición del "Infierno", Salamanca, 1974, p. 225. (ACS, 82.)

18 Otra obra medieval en prosa, cuya parte inicial muestra la tentativa abandonada de una versión en verso, es la traducción del Tractatus de Purgatorio Sancti Patricii (véase Antonio G. Solalinde, "La primera versión española de El purgatorio de San Patricio y la difusión de esta leyenda en España”, en Homenaje a Menéndez Pidal, t. 2, Madrid, 1925, pp. 222, 246.

19 "La première traduction espagnole de la Divine Comédie", en Homenaje a Menéndez y Pelayo, t. l, Madrid, 1899, pp. 269-307; la cita, p. 286. Véase también Schiff, La bibliothèque du Marquis de Santillane, París, 1905, pp. 275-304.

20 Arturo Farinell, Dante in Spagna, Francia, Inghilterra, Germania, Torino, 1922, pp. 91-92; Joaquín ARCE FERnándeZ, "La lengua de Dante en la Divina comedia" y en sus traductores españoles", RUM, 14 (1965), 9-48 especialmente pp. 23-26; Mario Penna, "Traducciones castellanas antiguas de la Divina comedia", RUM, 14 (1965), pp. 81-100; Pascual, ed. cit., pp. 17-27. Véanse ahora las observaciones de Derek Carr en su edición del Tratado de la consolación, de Villena, Madrid, 1976, (Clas. cast., 218), p. L.

21 Véanse Juan Antonio Pellicer y Saforcada, Ensayo de una bibliotheca, pp. 67-75; DAmián MÉndez RAYón, "La Eneida de Virgilio traducida 
b) El fragmento de las "Façañas de Hércules" (en verso). En el siglo pasado, Felipe Benicio Navarro identificó como "indudablemente" originales de Villena dos coplas en arte mayor de un poema titulado Façañas de Ércoles ( Hércules); las incluyó en la introducción a su edición del Arte cisoria (Madrid-Barcelona, 1879), p. xlvii. Según él, Villena escribió dos obrá sobre el mismo tema: las Façañas de Hércules en verso, y los Doze trabajos de Hércules en prosa. (Como explica Navarro, el error de Nicolás Antonio no fue el de identificar como poema la obra de Villena llamada De los trabajos de Hércules - pues existe, cree Navarro, por lo menos un fragmento de tal poema-, sino de confundir la edición publicada en Burgos - la obra en prosa- con el poema, pp. xlvii-xlviii). Añade que con toda probabilidad Villena escribió las Façañas en 1417 (p. xlix).

Encontró Navarro las coplas conservadas de las Façañas en la Bibliotheca formada de los libros $i$ obras públicas, de Don Ioseph Pellicer de Ossau y Tovar (Valencia, 1671), donde comenta Pellicer las profanaciones de los cartagineses en el templo de Hércules, ofreciendo las coplas (para él no de Villena sino anónimas) como ilustración:

Ansí lo entendió el Auctor del Poema intitulado de las Façañas de Hércules que escrivía en Metros Sáphicos (que llaman Coplas de Arte Mayor) en el Reynado del Señor Rey Don luan el Segundo, que hablando deste Sucesso de Therón, dize ansí en la Copia que está en Nuestro poder:

Empues que los Penos con el Filistines Robaron el Templo de Ércoles Primo, En Cádiz Fallaron Posada e Arrimo, Que nunca les Mengua alvergue a los Roínes, Hy levantaron Arteros Malsines, El Templo Novelo a Ércoles Tyrio, Ardiendo Contino el Bálsamo, e Cirio, Su Nombre se oyendo en lexanos Confines:

España del Rapto total se alborota, $\mathbf{E}$ un Rey que Estonce Therón se dezía, Cabdillo de Prez, e de Mucha Valía, Se Fizo a la Mar con toda su Flota

por D. Enrique de Villena", Revista Ibérica de Ciencias, Politica, Literatura, Artes e Instrucción Pública, 1 (1861), 443-455; URbano GonzÁlez dE la Calle, "Contribución al estudio de la primera versión castellana de la Eneida", Anales de la Universidad de Madrid (Letras), 2 (1933), 131-157, 259-284; 3 (1934), 1.20; Ramón Santiago Lacuesta, "Sobre los manuscritos y la traducción de la Eneida de Virgilio hecha por Enrique de Villena", Filologia Moderna, 11 (1971), 297-311. 
Devengar quixo el Denuesto, e la Nota,

Que aquel Filistines al Ércoles Fizo,

Pero los Penos con fuego hechadizo

Quemaron sus Fustas con falsa Derrota.

(Pellicer, Bibliotheca, folios $118 \mathrm{v}-119 \mathrm{r}$, citado en Navarro pp. xlvi-xIvii)

Por otra parte, Menéndez Pelayo opinó que las coplas copiadas por Pellicer, identificadas como versos compuestos en la época de Juan II, y que, según Navarro, formaban parte de una larga creación poética de Enrique de Villena ${ }^{22}$, eran puras invenciones de Pellicer (1602-1679): "En cuanto a las dos coplas de las Fazañas de Ércoles, insertadas en la Bibliotheca que de sus propias obras formó D. José Pellicer de Salas y Tobar, basta leerlas para ver en ellas la mano de un falsario del siglo xvn, probablemente del mismo Pellicer, bien abonado para este género de fazañas" (Antologia de poetas líricos, t. 2, Madrid, 1944, p. 49). De acuerdo con Menéndez Pelayo, Cotarelo y Mori (p. 123) y J. FitzmauriceKelly (Historia de la literatura española, trad. por A. Bonilla y San Martín, Madrid, 1914, p. 80) declaran sin fundamento la atribución a Villena.

En verdad, hay muy pocos motivos para señalar a Villena como autor de las Façañas. Si fueran auténticos los versos citados por Pellicer - si fueran del siglo xv como asegura- no parece muy probable que los escribiera Villena. El episodio nada tiene que ver con la materia que Villena incorpora a su obra en prosa sobre el mismo tema, Los doze trabajos de Hércules. Es una aventura o leyenda distinta, al margen de las que fueron recogidas en Doze trabajos. El asunto del fragmento de las Façañas sí se encuentra en la literatura de la época de Villena, pero más bien como mito algo nacionalista del cual se aprovechan los cronistas. Véase, por ejemplo, Pedro de Escavias, Repertorio de principes de España, caps. XI-xin, donde el autor hace un resumen del mito para describir los orígenes de las poblaciones de la Península y la fundación de sus ciudades (ed. Michel García, Jaén, 1972, pp. 26-30); también, Pablo de Santa María, Las edades del mundo, suplemento

22 A pesar de las dudas de Menéndez Pelayo y otros, Enrique Diaz-Retg confirma la opinión de Navarro en su edición del Arte cisoria (Barcelona, 1948), donde exagera aún más el papel de poeta de Villena: "Fue sobre todo en la poesía donde Enrique de Villena se prodigó en composiciones que debieron ser en número ingente, si bien casi nada ha llegado hasta nosotros salvo unas estrofas admirables en versos sáficos, pertenecientes a su poema Las Fazañas de Ércules. Poeta en relación constante con poetas, autor y mecenas al propio tiempo, mantenedor de juegos florales, fiestas del gay saber, de la gaya scientia desde Aragón a Cataluña y tierras provenzales de Francia..." (p. 37). 
sobre "El fundamento de la población de España" (ed. R. FoulchéDelbosc, Canc. cast. del s. $x v$, II, Madrid, 1915; NBAE 22, p. 181).

c) Libro del tesoro. Cabe examinar este largo poema como obra posiblemente auténtica de Enrique de Villena ${ }^{23}$. El Libro del tesoro consta de un breve prólogo en prosa (que no está incluido en todos los manuscritos), y dos "libros" en versos de arte mayor -el primero de 46 estrofas, el segundo de 28-, todo seguido de seis redondillas. Su asunto es así: El poeta, que se finge rey, tiene noticias de un gran sabio ("físico astrólogo") de Egipto que puede adivinar los acontecimientos futuros, $y$ otros vagos secretos universales ${ }^{24}$. Le escribe al sabio y, recibida la respuesta, viaja a su tierra para consultarle. Con los detallados consejos e instrucciones del sabio alquimista, el poeta-rey aprende a hacer el lapis philosophorum o "piedra filosofal" (= el tesoro del título). En realidad, el poema desde la estrofa 11 se reduce a la descripción de la construcción y el uso del lapis, y la tarea del poeta consiste en difundir la receta para su producción y la manera de utilizar sus varios poderes.

Aunque para su elaboración el Libro del tesoro sigue en todo momento los múltiples tratados medievales sobre alquimia, cuyo objeto es básicamente el descubrimiento y uso de los secretos de a piedra filosofal ${ }^{25}$, la fuente directa del poema atribuido a Vi-

23 Véase la edición de José Augusto Sánchez Pérez, "Libro del tesoro, falsamente atribuido a Alfonso el Sabio", $R F E, 19$ (1932), 158-180. Las ediciones anteriores son de Tomás Antonio Sánchez, Colección de poesias castellanas anteriores al siglo $x v$, t. 1, Madrid, 1779, pp. 148-170; AMAdor DE Los Ríos, Historia crítica, t. 3, pp. 681-694; José RAMón de Lucano, La alquimia en España: escritos inéditos, noticias y apuntamientos que pueden servir para la historia de los adeptos españoles, t. 2, Madrid, 1897, pp. 167-200. Según los apuntes de Fray Martín Sarmiento, Francisco de Quevedo poseía un manuscrito de "varios pensamientos sueltos para acomodar en coplas" que contenía, en la primera parte, el Libro del tesoro o Tesoro Chymico (véase José Luis Pensado, "Sobre la Vida de San Ildefonso y otras noticias literarias dieciochescas", $H R L, 2$, pp. 445-467, en las pp. 453-454).

24 Parece lugar común en las leyendas sobre la alquimia el motivo del viaje a la tierra del gran sabio alquimista, poseedor del secreto del lapis. Véase la biografía legendaria de Morienus (citada en A. E. Waite, Lives of Alchemystical Philosophers, Londres, 1888, pp. 53-56).

25 Cf. Alain de Lille (siglo $\mathrm{xm}$ ), Dicta de lapide philosophico. Son varias las obras posteriores en castellano sobre el tema: Luis de Centellas, Coplas sobre la piedra filosofal (publ. en Alcalá, 1552, pero escritas, según Amador de los Ríos, Hist. crit., t. 3, pp. 678-680, en la última parte del siglo xv) ; Diego de Torres Villarroel, Conversaciones físico-médicas de la piedra filosofal (1726), y El ermitaño y Torres, en que se trata de la piedra filosofal $(1752-1789)$. 
llena es el Liber lucis de Johannes de Rupescissa (m. 1362) ${ }^{26}$. En un artículo fundamental, pero muy poco citado, de P. MAzzeI, "Del Tesoro di Alfonso X e dei processi alchimistici", Archivum Romanicum, 12 (1928), 139-149, el autor indica la estrecha relación entre el Liber lucis y el Tesoro no sólo en las fórmulas y cálculos para las conversiones de los elementos, sino también en las dimensiones exactas de los instrumentos (p. 145). Para Mazzei, las actitudes científicas y las consideraciones métricas indican que el Libro del tesoro pertenece al siglo $\mathrm{xv}, \mathrm{y}$ que es obra de Enrique de Villena (pp. 141, 144, 145n4).

Para justificar provisionalmente la opinión de Mazzei, debemos indicar que las obras de Johannes de Rupescissa sobre la alquimia fueron conocidas por Villena. En un tratado inédito de Villena, la Exposición del verso IV del salmo VIII: "Quoniam videbo coelos tuos..", ofrece una referencia explícita al alquimista:

E porque este nonbre çielo es equívoco, e se entienden por él çinco maneras de çielos -es a saber, mediçinal, artifiçial, natural, real, supernal- segund en diversos auctores, siquier obras, do de aquéllos es fablado. De medisçinal, paresçe en el Libro de quinta esençia por Juan de Rocaçisa, e llamó çielo a la quinta esençia, sacada del agua ardiente, afirmando que tal puridat tiene sobre las otras mediçinas, como el çielo sobre los elementos ${ }^{27}$,

El autor del Libro del tesoro -como Johannes de Rupescissa antes que él- bosqueja las transmutaciones de los metales que se

26 Las obras de este franciscano han sido estudiadas por Lynn Thorndike, $A$ History of Magic and Experimental Science, t. 3, Nueva York, 1934, cap. 22, pp. 347-369, y Jeanne Bignami-Odier, Etudes sur Jean de Roquetaillade (Johannes de Rupescissa), París, 1962. Hay una versión catalana del siglo xv de su Vade mecum in tribulatione (1356) (véase Bignami-Odier, p. 248; Thorndike, pp. 352-353); una traducción al castellano, inédita y también del siglo $\mathrm{xv}$, se conserva en la Biblioteca Universitaria de Salamanca, ms. 1877, ff. 237-251, bajo el título "Libro de frey Johan de Rrocaçisa" (véase K. PIETsch, "The Madrid manuscript of the Spanish Grail fragments: Il", MPhi, 18, 1920-21, 139-140, quien ofrece algunos ejemplos; también, GuY Beaujouan, Manuscrits scientifiques médiévaux de l'Université de Salamanque et de ses acolegios mayores», Burdeos, 1962, pp. 82-83). El texto original del Liber lucis fue publicado por L. Zetzner en su Theatrum chemicum, t. 3, Estrasburgo, 1659, pp. 284-295. Beaujouan (p. 113), indica otra copia en la Bibl. Univ. de Salamanca, ms. 2108, ff. 59-65.

27 Biblioteca Nacional ms. 17814, fol. 132d. Sobre De consideratione quintae essentiae de. Johannes de Rupescissa, véase Thorndike, Magic, t. 3, pp. 355365. Fue editada la obra en el Theatrum chemicum, t. 3, pp. 359-485. José María Millás Vallicrosa, en las traducciones orientales en los manuscritos de la Biblioteca Catedral de Toledo, Madrid, 1942, p. 82, registra una copia (letra del siglo xv) de este texto, y Beaujouan (pp. 112-113) alude a otra de la Bibl. Univ. de Salamanca, ms. 2108, ff. 1-58. 
logran con la piedra, la encierra la esencia masculina (que produce el oro) y la femenina (que produce la plata). El problema o secreto de la piedra han sido sus ingredientes $y$, sobre todo, la prima materia o "quinta esencia"; el poeta hace un resumen de las teorías sobre el verdadero aspecto de la piedra, y ofrece su propia opinión (ed. de Sánchez Pérez, pp. 165-166) :

14. El nuestro Hermetis nos dice que es cielo e tierra, mas otros que es hombre y mujer, e del matrimonio se suelen hacer otros enigmas que sirven de velo: el ínfimo globo mostrado en el suelo le llaman algunos de agua y de tierra, otros el frío que al cálido encierra; tanto los sabios hubieron recelo.

15. Al antiguo Caos, a mi parecer, de cuatro elementos bien conglutinado aqueste compuesto es asemejado cuando diviso se viene a facer: el cielo y la tierra por sí viene a ser una quintaesencia e esencia de todo porque esta materia es fecha en tal modo que todas las cosas viene a conponer.

A continuación, formula el complejo proceso para elaborar la "quinta esencia" (estrofa 36e-f), e indica como exhibe la piedra, en las varias transformaciones (plata $[33 a-d]$, oro [33e-h], rubí [34a-h], $\mathrm{y}$, por fin, la prima materia [36c-f]), sus múltiples poderes:

37. Ente e principio de naturaleza no es oro, ni plata, ni otro mineral ni cosa sujeta a algún vegetal, mas disposición que a todo endereza: si al oro se aplica, de él toma firmeza para convertir en oro las cosas; si al home también, por obras famosas, le da sanidad con suma entereza (p. 171).

Describe luego las aptitudes de la piedra: la de multiplicar los metales, la de transformar el plomo en oro $(45 e-h)$, y su empleo como medicina más efectiva ("al flaco o al débil, le pone de suerte / que tanta salud no tuvo ninguno" [46e-f]). La parte final o el segundo libro (pp. 174-180) es una descripción de otros experimentos llevados a cabo con el lapis philosophorum, y en especial el de aislar en varias transformaciones los cuatro elementos. 
La atribución de tal poema curioso se basa en claras referencias a Enrique de Villena en la tradición manuscrita. Como señala Sánchez Pérez, el manuscrito de la Biblioteca Nacional termina con una nota del copista aludiendo a Villena ("Fue fallado este libro con los del magnífico caballero Don Enrique, señor de Villena, e fincó en poder del señor Rey"); los manuscritos de la Biblioteca de Palacio (ahora ms. 1795 de la Bibl. Universitaria de Salamanca, según Beaujouan, pp. 79-80) y de D. Francisco Javier de Santiago Palomares tienen esta misma nota final (Sánchez Pérez, pp. 159-160). Además, los manuscritos de la Biblioteca de Palacio (ahora de Salamanca) y de Palomares incluyen un párrafo que asocia a Enrique de Villena con el poema: "La cifra es dura de entender, mas fue explanada por mí, Don Enrique, señor que só de Villena; mas non fallé gracia en el Rey para que la mostrara, ca era bano onbre en ella, e oculté en poridad el su bien fasta el tiempo que Dios la dé (a) ome bueno" (Sánchez Pérez, pp. 160-161). Estas referencias a Villena, por supuesto, pueden constituir una ficción literaria -como la del falso prólogo (sólo en algunos manuscritos del Tesoro) que declara a Alfonso $\mathrm{X}$ el Sabio autor de la obra. Además, la fama de Villena como aficionado a las artes secretas alimenta una larga historia de falsificaciones $u$ obras espurias atribuidas a él ${ }^{28}$.

28 En la colección de cien cartas de cierto señor llamado Fernán Gómez de Cibdarreal, Centón epistolario (en Epistolario español, BAE, 13, Madrid, 1850, pp. 1-36), hay una carta (núm. LXVI) escrita a Juan de Mena, que incluye una descripción fantástica de la quema de la biblioteca de Villena. En la larga polémica sobre la autoridad del Centón entran Ticknor (History of Spanish literature, t. 3, p. 415: "the book is a forgery from beginning to end") ; Amador de los Ríos (Hist. crit., t. 4, pp. 351-364: "el Centón... ha gozado y gozará sin duda en adelante de autoridad legítima" [361]) ; Puymaigre ("Don Enrique de Villena", pp. 526-534, atacando fuertemente a Amador), y Waxman ("Chapters on Magic", pp. 395-396: "this book is now regarded as a forgery, belonging to the seventeenth century"), etc. En otra obra apócrifa, forjada en el siglo xvn, Carta de los veinte sabios cordobeses a don Henrique de Villena (ed. por José Ramón de Luanco, en La alquimia en España, t. 1, Barcelona, 1889, pp. 9.11; respuesta de Villena, pp. 12-24), los eruditos consultan a su maestro, Enrique de Villena, sobre la alquimia. Véase también Ricardo Olalla Mazón, Papeles de la alquimia de D. Enrique de Villena, Madrid, 1946. Problema aparte es el Libro o Tractado de astrotogia. Fue descubierto, descrito, y analizado por Manuel Serrano [y Sanz], "El mágico Villena", Revista de España, 142 (1892), 303-311. Lo consideraba muestra definitiva a la vez del conocimiento científico y de la ortodoxia general de Villena. Pero Cotarelo y Mori, pp. 100-101, rechazó la atribución a Villena, y Menéndez Pelayo, Antologia, t. 2, p. 40, también dudaba de su autoría. Segundo de Ispizúa, en su Historia de la geografia y de la cosmografia en las Edades Antigua y Media..., t. 1, Madrid, 1922, pp. 294-304, donde ofrece un resumen y varias muestras del texto del códice único, asegura que Vi- 
El primero en concluir que el Libro del tesoro era obra autén. tica de Villena fue Leandro Fernández de Moratín, en su Origenes del teatro español, publicado en 1830. Hablando del Libro del tesoro y el Libro de las querellas - atribuidos ambos a Alfonso $\mathrm{X}$-, opina: "si reflexiona que se hallaron entre los manuscritos del marqués de Villena, sospechará quién pudo ser el verdadero autor, y a cuál época pertenecen" (p. 15). Ticknor (I, p. 4l) no acepta

llena es su autor. El problema es que el único manuscrito fue copiado por Andrés Rodríguez en 1438 y es dificil averiguar hasta qué punto Rodríguez es fiel a una versión original de Villena, o añade otros materiales. Francisco Vera, "El Tratado de astrologia del Marqués de Villena", Erudición Iberovltramarina, 1 (1930), 18-67, ofreció una descripción completa, un resumen de cada capítulo, y largos extractos del texto. Por razones estilísticas - poco desarrolladas- y por las declaraciones de Cotarelo, descarta a Villena como posible autor. En este importante artículo, descubre Vera que el autor del Tractado había incorporado en su obra muchas secciones (caps. IV-VIII) de la traducción castellana hecha por Alfonso de Paredes y Pero Gómez del Libro del tesoro de Brunetto Latini, aunque Villena no cita esta fuente en ningún lugar. (Curiosamente, un estudio muy reciente de Amanicio LAbanderra FerNÁNDEz, "Un cronista español del siglo xv, Pero Rodríguez de Lena, entre la ciencia de Brunetto Latini y la nobleza de Suero de Quiñones", RABM, 79 , 1976, 73-95, muestra que muchos de los trozos de Latini que entran en Astrologia fueron incluidos en el Passo Honroso). Otro estudio sobre el texto fue elaborado por José María Millás Vallicrosa, "El Libro de astrologia de Don Enrique de Villena", RFE, 27 (1943), 1-29; hay un resumen del contenido, también con extractos, y amplios comentarios útiles sobre las fuentes citadas ( $y$ a veces inventadas) por Villena. Para Millás, Villena es sin duda el autor: "De nuestro estudio creemos poder deducir que el tratado astronómico, Libro de astrologia, representa una obra original de Don Enrique de Villena, la cual guarda cierta analogia de fondo, forma y fuentes con otras obras suyas" (p. 29). Fenómeno curioso es que Millás nunca había visto el estudio de Vera, pero ambos, independientemente, descubrieron los mismos elementos importantes en la composición de la obra; Millás también nota que para unos trozos largos sobre los cuatro elementos, los planetas, etc. (caps. IV-XV) Villena se aprovecha libre y literalmente de otro texto contenido en el ms. 10011 de la Biblioteca Nacional (manuscrito que había descrito en su obra Las traducciones orientales. ., pp. 132-141). No se dio cuenta Millás de que fueron extractos de una traducción de Latini, aunque al tratar de identificar las fuentes señala a Guillermo de Conches (p. 133) y otros autores, que fueron las fuentes para Latini. Probablemente, Villena sacó la materia de un compendio -como el del ms. 10011 de la Biblioteca Nacionalsin enterarse de su verdadero autor. Además, como indica el trozo citado por Vera (p. 51), Villena inventa fuentes ("Abumasar e Guillermo e Alfragano...") para la materia en los pasajes de Latini. La obra de Villena que se relaciona más estrechamente con la Astrología -y que, en efecto, prueba que Villena es autor de la Astrologia- es la Exposición del salmo "Quoniam videbo..." (inédita); incluye las mismas fuentes (Alberto Magno, Alfargano, Tolomeo), y trata de los mismos asuntos (la descripción de la luna y el sol, los movimientos celestiales, las supersticiones relacionadas con la astrologia, etc.). 
las especulaciones de Moratín; es Amador de los Rios quien censura severamente a Moratín y a los otros que atribuyen a Villena el Libro del tesoro (Historia critica, t. 3, p. 678). Aunque admite Amador que el manuscrito del Libro examinado por él es de fines del siglo xv (ibid., p. 679) o, por lo menos, "posterior a la primera mitad del siglo xv" (p. 521), tales versos no pueden proceder de la mano del mismo poeta a quien elogia Amador tan altamente en otro lugar (VI, p. 76). Eliminando a Villena, Amador propone como autor del Libro del tesoro a un tal Alarcón, alquimista al servicio del arzobispo de Toledo, D. Alonso Carrillo (1446-1484) (III, pp. 519-520 y 679) -hipótesis más infundada y precipitadamente formulada, a nuestro parecer, que la de Moratín ${ }^{29}$. MENÉndez Pelayo, Antología, t. 2, p. 39, también clasifica como obra apócrifa el Libro del tesoro.

En rigor, sería atrevido y peligroso afirmar definitivamente que el Libro del tesoro es una creación de Enrique de Villena. Los versos en sí -como apunta Mazzei- no lo descartan. Pueden ser de la época de Villena, ya que se utiliza vocabulario y sintaxis latinizante que encontramos en los poetas de su tiempo (I.14e "infimo globo", $25 b$ "nítido azogue", $31 e$ "del líquido humor", 34f "diáfano cuerpo color de rubi"; $11.12 c$ "en días cuarenta se viene acabar"). En cuanto al aspecto técnico (la rima, el metro), los versos delatan un escritor competente o experimentado. El tema, por supuesto, no da lugar a los elevados momentos poéticos de la alegoría o el elogio; incluso el empleo del arte mayor y los extravagantes cultismos de su época con materia tan ajena casi hacen pensar en una dimensión humorística.

Hay que admitir que a pesar de la fama póstuma de alquimista que goza Villena ${ }^{30}$, lo referente al arte de la alquimia sólo ocupa un lugar secundario en los escritos suyos que se conservan. En su Tractado de astrologia se menciona esa profesión o ciencia. El capítulo III es un estudio general de los elementos del universo - una introducción a los capítulos siguientes sobre cada uno de ellos. (Parece que el cap. III es obra original de Villena; los capítulos sobre los elementos particulares (V-VIII) son mayormente extractos de una traducción de Brunetto Latini). Establece Villena que los elementos simples "no son convertibles nin resulubles", si bien los elementos compuestos son "convertibles e resu-

29 F. Rodrícurz Marín parece sugerir que Villena es autor del Libro del Tesoro, en Felipe II y la alquimia, Madrid, 1927, pp. 15-16.

30 Florece esta tradición en la Carta de los veinte sabios cordobeses. En la respuesta de Villena, habla de un sueño en que se le aparece Hermes, dándole las llaves de la arqueta que contiene todos los secretos de la alquimia (La alquimia en España, ed. Luanco, t. 1, pp. 12-24). 
lubles, e non de aquello que es' ylle" (Vera, p. 29; Millás Vallicrosa, p. 10). Como prueba de todo esto, cita a Moisés y a Aristóteles: "cada cosa se resuelve en aquello de que fue compuesta" (Vera, pág. 29). Después, Villena advierte a los alquimistas "que se afanan de convertir un methal en otro", que deberían determinar primero "qué es lo que convierten o resuelven" (Vera, p. 29). Estas palabras pueden interpretarse casi como una censura a las actividades alquimistas que se describen en el Libro del tesoro; por otra parte, pueden indicar que Villena se considera autoridad en tal ciencia. También hay referencias a las obras de Hermes Trimegistro en otras obras de Villena, como en el Libro del tesoro (1.14a-b "El nuestro Hermetis nos dice que [la piedra filosofal] es cielo / e tierra...") ${ }^{31}$. Compárese Exposición del verso IV del salmo VIII (1424): "De la segunda materia [de los çielos] paresçe en los Secretos de Hermes que los materiales, por artefiçio dipurados, e allegados a la incorrubtibilidat, e sinpleza les dize" (Bibl. Nac. ms. 17814, fol. 132d). También cita Villena las obras de Hermes en el Arte cisoria: "el tractado de las trasmutaciones e leyes del vevir e reglas del ánimo dar, que fizo Hermes, que es dicho Enoc e Tubal Caym en la música e Yubal en la fusión de los metales, amos fijos de Adam..." (ed. Navarro, p. 13).

Como hemos visto, el poema consiste básicamente en una relación en verso de las extrañas doctrinas de Johannes de Rupescissa sobre la alquimia, aunque a veces añade el poeta referencias originales a la mitología. Por supuesto, estas añadiduras de fuentes tan familiares a los eruditos del siglo xv no confirman que sea Villena el autor del Libro del tesoro. Pero a veces son los mismos mitos que Villena cita en obras ciertamente suyas. Por ejemplo, describe así el poeta la transformación en aire (ed. Sánchez Pérez, p. 179) :

II.25. Cual fue Ganimedes al Cielo subido así la materia veréis exaltada del Dios de la tierra será demandada a Joves, que el robo hubo cometido...

Villena, en su Epistola a Suero de Quiñones, resume y aplica el mismo mito de esta manera: "E allí mesme [Ovidio, Metamorfosis] parece quanto persiguió [Júpiter] al ynfante Ganimedes, e volun-

31 En la Edad Media, por supuesto, cualquier tratado que tenga que ver con las artes secretas invoca las obras apócrifas de Hermes. Sus obras sobre la alquimia incluyen Tabula smaragdina, que pasó del árabe al latín, y llegó a formar parte del Secretum secretorum del seudo-Aristóteles, y el libro de alquimia, Hermes in alchimicis, citado por Alberto Magno. 
tariamente obtener no lo pudo, hasta que por violente mano lo arrebató en sus aquilinas uñas, en el dezeno libro parece" 32 .

Todas las pruebas secundarias - el paralelismo entre temas del poema y las obras de Villena, las referencias explícitas a Villena en la tradición manuscrita, las prácticas métricas y retóricas que confirman la autenticidad cronológica- conducen a una clasificación provisional del Libro del tesoro como obra muy posiblemente escrita por Villena. De nuevo, las dudas que quedan no provienen de una falta de evidencia textual, sino de la carencia de otras composiciones poéticas de Villena con las que verificar su capacidad creadora en ese género. Además, incluso si fuese el Tesoro obra de Villena, no constituiría base suficiente para los elogios del papel importante que supuestamente desempeñó en el mundo poético: se trata más bien de un ejercicio marginal que de una pieza capaz de suscitar la rendida admiración de una época.

d) Versos del "Marqués de Villena" en el "Cancionero de Hernando del Castillo" y el "Cancionero de Constantina". Como ya se ha mencionado, varios investigadores han atribuido a Enrique de Villena unos versos -fragmentos, posiblemente, de dos poemas largos- recogidos en los cancioneros del siglo xvi. Eleuterio F. Tiscornia, en sus notas al fragmento de Argote de Molina sobre las "coplas y canciones" de Villena (véase supra, p. 64) para la edición moderna de su Discurso sobre la poesía castellana (Madrid, 1926), cree que bastan para confirmar la opinión de Menéndez Pelayo unos versos de Enrique de Villena en el Cancionero de Hernando del Castillo. Asegura Tiscornia en un párrafo algo hermético: "Desvanécense del todo las dudas sobre la infecundidad poética de Villena cuando se comprueba que el Cancionero de Hernando del Castillo ... es el único que recoge cinco versos suyos, repetidos después en el Cancionero de Constantina..." (pp. 81-82).

Los versos identificados así como auténticos de Enrique de Villena aparecen en el Canc. general recopilado por Hernando del Castillo (Valencia, 1511; ed. facsimilar de A. Rodríguez-Moñino, Madrid, 1958), en la pieza que lleva el título "Aquí comiençan las invenciones y letras de justadores y tanbién lo que Cartagena dixo a algunas dellas declarando su parecer":

32 Citamos de los extractos de la Epistola publicada por Cotarelo, "Una obra desconocida de don Enrique de Villena", $R H i, 2$ (1895), p. 99; hay una edición completa y esmeradamente anotada por Derek C. Carr, "La Epistola que enbio Don Enrrique de Villena a Suero de Quiñones y la fecha de la Crónica Sarracina de Pedro de Corral", en University of British Columbia Hispanic Studies, ed. H. Livermore, London, 1974, pp. 1-18. 
El Marqués de Villena sacó una mata de una yerva que dizen siempre biva y dixo:

Muera la vida,

y la fama sienpre biva.

Otra del mismo Marqués avia bordadura de una boças que ponen a los perros:

La señora cuyo soy

me mandó quéstas truxesse,

por que quexas no le diesse (fol. cxxxxi", col. c).

Otra vez, una de las dificultades en la identificación de los versos es el título nobiliario con que se nombra al poeta: ¿es Enrique de Villena, llamado erróneamente "Marqués de Villena", o Diego López Pacheco, auténtico Marqués de Villena? Varios bibliógrafos y críticos modernos, de acuerdo con Tiscornia, concluyen que se refiere a D. Enrique. José SImón Díaz, Bibliografia de la literatura hispánica, vol. 3, t. 1, pp. 355, 389, 493, y ANTonio RoDRíguez-MoÑINo, Manual bibliográfico de cancioneros y romanceros (Madrid, 1973), I, p. 41, núm. 533, y II, p. 915, citan en sus índices a Enrique de Villena como autor de estos poemas. Maria Rosa Lida DE Malkiel, La idea de la fama en la Edad Media castellana (México-Buenos Aires, 1952), pp. 230, 310, comenta los versos como ilustraciones de las actitudes de Villena: "El ansia de perdurar en la memoria de los hombres, que aqueja agudamente al inquieto siglo $\mathrm{xv}$ español, halla formulación perfecta en la divisa del Marqués de Villena [= Enrique de Villena en su índice], uno de sus hombres más representativos hasta en su frustración intelectual y desbaratada existencia...: «Muera la vida / y la fama siempre viva»" (p. 230).

Las dificultades de una identificación positiva del poeta se multiplican si se tiene en cuenta el género extraño del poema en el que se incluyen sus versos. Es un tipo de amalgama o miscelánea de trozos de varios poetas, agrupados con motivo de una "justa poética" que preside Cartagena. Este contexto ni siquiera garantiza que los fragmentos sean siempre auténticos e ilustrativos de los poetas nombrados por Cartagena. Lo que apoya la atribución a Pacheco y no a Villena es la compañía de poetas en que aparecen las muestras de poemas del "Marqués de Villena". Casi todos son posteriores a la época de D. Enrique (m. 1434) y más contemporáneos a la de Pacheco (m. 1474): Jorge Manrique (m. 1479), fñigo de Mendoza (m. 1507?), Diego López de Haro (m. h. 1500), etc. (De todos los poetas incluidos en esta curiosa antología, parece que Álvaro de Luna fue el único que floreció como escritor 
en la primera mitad del siglo $\mathrm{xv}$ ). Pero, si hay una relación entre los versos escogidos por Cartagena y la vida o la leyenda de los poetas citados, los versos ( $y$ las breves introducciones que relatan cómo fueron copiados o presentados) se ajustan mejor a Enrique de Villena. Es decir, la ornamentación o bordado de la "yerva que dizen sienpre biva" y los versos "Muera la vida / y la fama sienpre biva" parecen más propios de Villena que de Pacheco. ¿Quizá estos versos quieran evocar la leyenda creciente de Enrique de Villena en la segunda mitad del siglo xv, leyenda de practicante de las artes secretas $y$, a la vez, contemplador de las cosas eternas?

Pero incluso si queda la posibilidad de que los versos se refieran a Villena y no a Pacheco, sería difícil edificar una reputación de poeta a base de tales fragmentos. Parece muy posible que en este ejemplo Cartagena no esté citando o recogiendo versos existentes, sino inventando textos apropiados para cada poeta en una reunión ficticia de artistas. Tal vez no busca una autenticidad textual, sino un reflejo acertado del carácter biográfico y literario de los poetas aquí convocados.

e) El drama alegórico de 1414. Tampoco podemos juzgar con exactitud el papel de Enrique de Villena en la composición y la puesta en escena del drama alegórico presentado con motivo de la coronación de su primo y amigo, Don Fernando de Antequera, en Zaragoza, en 1414. Numerosos investigadores han declarado que Villena era el autor del drama. El primero en señalar a Villena como dramaturgo fue Blas Nasarre en el prólogo a su edición de Cervantes, Comedias y entremeses:

En la familia real de este príncipe [Alfonso IV de Aragón] se vinculó la gracia, y estudió la poesía, hasta el famoso don Enrique de Aragón, Marqués de Villena, Maestre de Calatrava, su biznieto, que compuso arte de la Gaya Ciencia, y muchas poesías, y diá. logos, que se representaron y celebraron. De Gonzalo García de Sama María, chronista del rey don Fernando el Honesto, consta que una comedia compuesta por el Marqués se representó en $\mathrm{Za}$ ragoza a los reyes, en la qual hacían su papel personalizadas la Justicia, la Verdad, la Paz, y la Misericordia, de que se infiere la vanidad de los que se atribuyeron dos siglos y más después la invención de poner en el theatro las cosas espirituales figuradas en apariencias (Comedias y entremeses ... con dissertación, o prólogo sobre las comedias de España, Madrid, 17b9, I, fol. B2r).

La atribución se instala como dato incontrovertible en la historia literaria: la registran Luis José Velázquez, Orígenes de la poesía castellana (Málaga, 1754), p. 95; Juan Antonio Pellicer y SAFORCADA, Ensayo de una bibliotheca, p. 63; Modesto LAfuente, 
Historia general de España, IX (Madrid, 1852), pp. 73-74; CAYETANo DE LA BARRERA Y LEIRADo, Catálogo bibliográfico del teatro antiguo español (Madrid, 1860), p. 15. Para George TICkNoR, History of Spanish literature, I (Boston, 1849), p. 235, la referencia a un drama moral de Villena sirve para aumentar las noticias de un teatro activo en la primera parte del siglo xv; además, cree Ticknor que Jerónimo Zurita se refiere explícitamente a la obra de Villena cuando menciona los "grandes juegos y entremeses" presentados para la coronación de Fernando, en los Anales de la Corona de Aragón, libro XII, año 1414. También Amador DE Los Ríos, Historia critica, VI, p. 75, opina que Villena fue sin duda el autor ${ }^{\mathbf{3 3}}$.

Desgraciadamente, el texto original del espectáculo, en catalán, ya no se conserva. Pero la primera parte de una crónica de Alvar García de Santa María, que describe principalmente las actividades de Don Fernando de Antequera en los años 1406-1419, ofrece abundantes y detalladas noticias de la representación alegórica ${ }^{34}$. En el siglo pasado, Alfred Morel-Fatio editó los trozos que se conservan en Romania, 26 (1897), 127-129 ${ }^{35}$.

García de Santa María -uno de los dos mil huéspedes reunidos para el banquete y la fabulosa representación ${ }^{36}$ - describe los pormenores de la escenografía suntuosa, de la acción alegórica, e incluso de los trajes de los actores. En el prólogo, un ángel des-

33 Opinión semejante expresan E. Dorer, art. cit., p. 131; Milá y Fontanals, "Orígenes del teatro catalán", Obras completas, t. 6, Barcelona, 1895, pp. 238-240; Adolfo Federico, Conde de Schack, Historia de la literatura y del arte dramático en España, trad. por E. de Mier, t. 1, Madrid, 1885, pp." 233237; Cotarelo y Mori, pp. 37-38.

34 Esta primera parte, inédita, se conserva en el ms. Esp. 104 de la Bibliothèque Nationale, París; la segunda parte (años 1420-1434) ha sido editada en la Colección de documentos inéditos para la historia de España, ts. 99 y 100 .

35 I. I. Macdonald ha estudiado cuidadosamente este pasaje, en Don Fernando de Antequera, Oxford, 1948, pp. 200-201. En un artículo donde examina otra sección del texto inédito de García de Santa María, "A Coronation Service of 1414", MLR, 36 (1941), 351-368, nota 2, alude Macdonald a otro trabajo suyo sobre el drama atribuido a Villena, que iba a publicarse en Bulletin Hispanique, pero parece que su estudio se perdió durante la guerra. Sirviéndose del mismo ms. Esp. 104 de la crónica de García de Santa María, publicó Charles V. Aubrun un estudio detallado del drama de 1414, "Sur les débuts du théâtre en Espagne", en Hommage a Ernest Martinenche: Etudes hispaniques et américaines, París, sin fecha (aunque se cree publicado en 1939), pp. 293-314. Más recientemente, N. D. Shergold ha aprovechado de este material para la amplia descripción del espectáculo de 1414 que ofrece en $A$ History of the Spanish Stage from Medieval Times until the End of the Seventeenth Century, Oxford, 1967, pp. 116-119.

36 Véase Macdonald, Don Fernando de Antequera, p. 201. 
ciende en una nube mecánica, trayendo para el nuevo rey de Aragón unos versos de la Santa Trinidad sobre sus deberes. Éstos son los únicos versos del drama que cita García de Santa María, traducidos al castellano:

E comiendo el dicho manjar primero, Dios padre movió todos los çielos, e dende partió una gran nube, e descendió delante de la mesa en ygual de los paños franceses, que estavan puestos en la sala, alto del suelo como una lança d'armas, e salió de la nube un ángel cantando, trayendo en la mano una espada desnuda de la vayna, ó dixo dos coplas asy en limosín:

Dios te salva, rey magnífico con coraçón fuerte.

La Trenidad santa e verdadera

a ti me ynvía como a flor d'España.

Que te mantengas sienpre en buen conorte,

y reposarás alto en los cielos,

con arcángeles, do es muy fuerte castillo.

Encomiéndote todo el pueblo menudo,

que entre los grandes non sea mal caydo,

peloar mucho fuerte de verdadera crisma.

Defendedor de la clara fee,

la yglesia de Dios a ti se encomienda,

creyendo çertamente que le quitarás la çisma,

llevando el santo padre allá,

dentro en Roma syn toda fallençia.

Obedecerle-hán con gran reverençia,

e çesarán las çismas d'aquí adelante.

E acavando de dezir la nube, subió el ángel a los çielos, e los de parayso tocaron sus estromientos faziendo grande alegria. (ms. Esp. 104, fol. 199v; trozo citado por Morel-Fatio, pp. 128-129, MACDONALD, Don Fernando de Antequera, p. 161, y Ch. Aubrun, "Sur les débuts du théâtre", p. 299).

El asunto del drama es una batalla alegórica entre los siete pecados y las siete virtudes; cada uno recita versos y hace un juguete o paso cómico para ilustrar exageradamente sus tendencias. (Véase el texto de García de Santa María, en Morel-Fatio, p. 129, y las descripciones completas en Aubrun, pp. 300-301, y Shergold, pp. 118-119.) Termina la representación con la aparición de la figura de la Muerte.

Aunque la atribución del espectáculo alegórico zaragozano a Enrique de Villena (como autor y director) ha sido una opinión bastante extendida entre historiadores de la literatura desde el siglo xvirI, la base de esta atribución es más intuitiva que concreta. Como señalan Morel-Fatio (p. 127) y otros, Álvar García 
de Santa María no dice en ningún momento que Vdlena hubiera estado a cargo de la representación del drama ni que fuera el autor de estos versos ${ }^{37}$. Por eso, Morel-Fatio ha eliminado decididamente la posibilidad de que Villena fuera dramaturgo: "En somme, il faut rayer des oeuvres attribuées malencontreusement à Villena ces strophes de circonstance dues à quelque rimeur catalan dont nous n'avons guère à regretter de ne point savoir le nom" (p. 129).

Por otra parte, es fácil comprender que los investigadores antiguos declaran automáticamente a Villena autor del drama de 1414, sin dar lugar a dudas. ¿A quién en la corte de Fernando de Antequera le habrían sido encargados los planes, la producción, y el texto de un espectáculo alegórico tan impresionante, sino a Enrique de Villena? Villena tiene un papel importante en los asuntos de la casa de su primo, y le habría parecido natural ocuparse de los detalles de la representación. Es Villena quien, tal vez ese mismo año, organiza las fiestas poéticas de Barcelona. Además, como sugiere Aubrun (p. 305), la organización del espectáculo -e incluso la composición del texto del drama- no sería para Villena un proyecto atrevido o ajeno a su experiencia. El joven Enrique de Villena, a los catorce años, había asistido a las fiestas (sin duda semejantes) de la coronación de Martín el Humano, y conocía la fórmula dramática de tales representaciones. Queda un margen mínimo para la especulación en el asunto del nombramiento de Villena como autor y empresario, pero parece una atribución bastante bien fundada.

Como queda indicado, el mito de Villena, poeta, se ha difundido tanto como el de Villena, nigromante y poseso; entre los partidarios de una inspiración fecunda, origen de poemas hoy desaaparecidos, y los de una producción poética mínima, frívola, o incluso inexistente, el enfrentamiento ha sido tan constante como entre los que discuten sobre su fama de mago. Como conclusión inicial, hay que admitir que su creación poética no puede haber sido muy extensa. En la tardía Edad Media castellana, casi cualquier pieza poética - sea de un aficionado o de un artista notable- tiene cierta garantía de entrar en uno de los infinitos cancioneros. Es verdad que algunos cancioneros se han perdido, y que a otros les faltan varias hojas, pero muchísimos de los poemas perdidos nos son conocidos por su título, su primer verso, o algún

87 Véanse también Milá y Fontanals, "Orígenes", p. 239, nota I; ME. nÉndez Pelayo, Antologia, t. 2, pp. 34-35; Aubrun, p. 304. FrtzmauriceKeLly, Hist. de la literatura española, p. 79, refleja la opinión de Morel. Fatio: "Erróneamente se le atribuyen [a Villena] unas insignificantes coplas escritas con ocasión de las fiestas celebradas en Zaragoza". 
otro indicio. Por lo tanto, la falta no sólo de poemas de Villena, sino también la falta de indicios seguros de poemas perdidos, constituye una prueba bastante fuerte. Compárense sus obras en prosa: se ha perdido una, pero de la mayoría sobreviven múltiples copias manuscritas, incluso de sus cartas personales ${ }^{38}$.

En cuanto a las obras que los críticos proponen como restos de nuestro hipotético cancionero de Villena -restos sumamente variados en su propósito, su asunto y su estilo-, no se les puede eliminar grosso modo como composiciones apócrifas. Las estrofas conservadas de las Façañas de Hércules no son, de ningún modo, de Villena: en primer lugar, es muy posible que fueran forjadas por un erudito del siglo xvn; incluso si fueran del siglo $\mathrm{xv}$, no hay nada que las relacione con Villena si no es una aparente coincidencia con la obra en prosa que lleva un título semejante. Tampoco podemos emplear los versos del Cancionero de Hernando del Castillo como pruebas de la existencia de otra clase de poemas de Villena: si se atribuyen a él (lo cual resulta muy problemático) y no a Pacheco, es imposible averiguar si son versos auténticos del poeta, o versos que recogen el carácter del poeta, inventados por Cartagena.

Por otra parte, existen pruebas más decisivas de que Villena pudo escribir el poema en arte mayor llamado Libro del tesoro. La obra coincide con los temas de Villena y con los métodos de su época, y las curiosas declaraciones de los manuscritos medievales parecen auténticas. En el caso del drama de 1414, no hay ninguna nota que declare autor a Villena, pero su posición en la corte de su primo casi le confirma como primer artífice de tal proyecto.

Lo extraño es que Villena, a pesar de su participación evidente en las actividades poéticas de la primera parte del siglo xv, como traductor de las obras que dan un nuevo ímpetu a los temas y formas poéticos de su época, a la vez que preceptista y teórico de una generación, no haya dejado muestras seguras de una obra poética ${ }^{39}$. Los elogios de sus contemporáneos continúan siendo un

38 Véase el inventario preliminar de manuscritos de Villena en Bibliography of Old Spanish Texts: Literary Texts, ${ }^{2}$ ed., Madison, Wisconsin, 1977, pp. 43-45.

39 En la sección IIb de nuestro artículo, tratamos un poema casi seguramente apócrifo, Las façañas de Hércules. Adviértase que hay otro poema atribuido a Villena, que no parece ser de él, ni siquiera del siglo xv: Pronóstico del Marqués de Villena del año de mill y seiscientos y de la conjunctión máxima del año de 1603 de diziembre. Véase el Tratado de la consolación, ed. Derek C. Carr, pp. lvi-lvii, donde se reproducen dos estrofas. En la nota 28, donde hablamos de la discusión sobre la autoría del Libro de astrologia, debíamos haber mencionado a Bernardino Martín Mínguez. En su curioso libro, Salpicaduras histórico-literarias: los condes de Castilla y los infantes de Lara, Madrid, 1915, dedica un capítulo (pp. 273-304) a una crítica severa de Co- 
enigma: en lugar del rico acervo de poemas originales que prometen, no nos han llegado sino trozos dispersos de una producción esporádica y heterodoxa ${ }^{40}$.

JoHN K. WALSH

University of California, Berkeley.

Alan Deyermond

Westfield College, University of London;

Princeton University.

tarelo por su supuesta falta de respeto para con Villena. Martín Mínguez acepta la Astrología como obra auténtica de Villena (pp. 287-289). Al corregir las pruebas de nuestro artículo, vimos el de Elena Gascón Vera, "Nuevo retrato histórico de Enrique de Villena (1384-1434)", $B R A H, 175$ (1978), 107-143, que ha de tomarse en cuenta para todo estudio futuro de Villena.

40 Agradecemos sinceramente al profesor Luis Fernández Cifuentes su cuidadosa revisión del texto español de este articulo. 